\title{
Examining Consumer-Brand Relationships in the UK Energy Sector: A Social Media Perspective.
}

\author{
Emmanuel Mogaji \\ University of Greenwich, London, UK \\ e.o.mogaji@greenwich.ac.uk \\ Dandison Ukpabi \\ University of Jyväskylä, Jyväskylä, Finland \\ dandison.c.ukpabi@jyu.fi \\ Sunday Olaleye \\ University of Oulu, Oulu, Finland \\ sunday.olaleye@oulu.fi
}

\begin{abstract}
With social media transforming how customers interact with brands, this study explores the consumer -brand relationship in UK energy sector which has a reputation for lack of trust by customers. Using user-generated contents on Facebook pages of the 'big six' UK energy companies, the study qualitatively operationalised and applied three consumer-brand relationships construct, exploring the interplay between the brands and the consumer. Findings revealed various indications of brand trust, satisfaction and affiliation but overall customers are not satisfied with their relationship with energy companies, they want to know there is a brand on their side, who takes an interest in their complaints and is willing to help them out. There were forms of engagement and a sense of attachment through brand icons and winning prizes through competition. The consumers found social media a more accessible, cheaper, faster means of communicating, they often offer compliments, complain or requests for assistance. The study extends understanding of energy brands and consumer relationships and advances knowledge on the emerging research approach of thematic analysis; by extracting and analysing consumer comments on social media.
\end{abstract}

Keywords: Energy company, UK, social media, thematic analysis, brand relationship, brand

\section{Introduction}

Building relationships with customers is considered crucial in assuring brands' long-term business success (Tuškej, Golob, \& Podnar, 2013). Thus, consumer scepticism toward brands is a concern for both scholars and practitioners. The UK utilities sector has a reputation for a lack of trust by customers - similar to the banking sector - because they are often perceived to not offer services in the best interests of their customers and wider society (Rogers, 2014). 
The UK Energy industry has over 90 members that produce energy from renewable sources, as well as nuclear, gas and coal. The energy industry adds $£ 87$ bn to the British economy and supports one in 49 jobs in the UK (Energy UK, 2017). Interestingly, despite this size, the renowned 'Big Six' energy companies play a dominant role and control the largest market share in Britain's energy sector. These are British Gas, EDF Energy, E.ON UK, npower, ScottishPower and SSE. The Big Six currently provide gas and electricity to around 26 million UK homes.

There is disruption within the industry (Vaughan, 2017), and with a huge number of smaller suppliers gaining a greater foothold in the UK, they are well placed to challenge the market domination of the Big Six. The industry is under intense political scrutiny and faces the introduction of a price cap on default tariffs in early 2019. In light of this pending competition, these brands need to evaluate their customer relationships.

The brand-consumer relationship in different sectors has been explored in literature. However, to the best of our knowledge, literature on the relationship between energy brands and their customers is scarce, highlighting a gap in our understanding of service brands. The lack of trust, competition in the industry, concerns around climate change and environmentally friendly energy sources present justifications to understand the relationship between these brands and the customers.

As social media has transformed how customers interact with brands (Tsai \& Men, 2013), it offers the opportunity to find out consumers' perceptions of brands and their competitors. Like any other media source, social media has become an important communication platform for customers to explicitly connect with brands (Chu, 2011). This study utilises grounded theory and Esch, Langner, \& Schmit (2006) consumerbrand relationship construct to explore the consumer-brand relationships in the UK Energy industry, focusing on the Big Six by using qualitative data extracted from Facebook.

Against this backdrop, our study makes two key contributions to the literature. First, it extends understanding of energy brands and consumer relationships by qualitatively operationalising the Esch, Langner, \& Schmit (2006) consumer-brand relationship construct. Second, our study advances knowledge on the emerging research approach of netonographic exploration of Facebook community by extracting and analysing consumer comments on social media, insights can be obtained on consumers' perception of brands.

\section{Literature Review}

Customers can experience a deep emotional attachment towards brands, something considered the most reliable indication of how strong a brand is (Karjaluoto, Munnukka, \& Kiuru, 2016; Pawle \& Cooper, 2006), In fact, previous research suggests that customers consider brands as humans with which they can build and maintain relationships following their direct and indirect contact (Sung and Choi, 2010; Sung and Kim, 2010). This consumer-brand relationship is considered vital for brands' survival and prosperity as it leads to brand loyalty and contributes to increased repurchase volume and better acquisition rates (Sabrina \& Shobeiri, 2016; Giovanis, 2016). 
Evaluation of the strength of the relationship is considered important to ensure continuous patronage. To this end, Fournier (1998) developed one of the models to evaluate the consumer-brand relationship. However, Fournier's model has been criticised as many scholars do not fully agree on the dimensions of the consumer-brand relationship (Bengtsson, 2003). Consequently, this has therefore led to the development of many other models among which is Esch et al. (2006)'s three components of brand trust, brand attachment and brand satisfaction.

There are several previous studies that have evaluated consumer-brand relationships in different service contexts, including industries such as service brands in mobile internet services (Giovanis, 2016), the telecom service sector (Izogo, 2017) and financial services (Mogaji \& Danbury, Making the brand appealing: advertising strategies and consumers' attitude towards UK retail bank brands, 2017). However, studies of the relationships in the energy sector are rare, with the exception of the study of private energy customers in Germany (Walsh, Dinnie, \& Wiedma, 2006). This is the gap this study aims to fill.

With the understanding that a significant competitive advantage for a service brand can be achieved by building and maintaining a mutually beneficial relationship with customers (Giovanis, 2016; Veloutsou, 2015), the current study operationalised Esch, Langner, \& Schmit's (2006) construct to investigate consumer brand relationships in the UK energy sector.

\section{Methodology}

The research was designed to be exploratory in nature, aiming to understand the consumer-brand relationship in the UK energy sector, based on consumer reviews on social media. Facebook was chosen for this study because, as the biggest social-media brand, it offers customers the opportunity to interact with brands and express their feelings towards them (Kang, Tang, \& Fiore, 2014).

Understanding technology transformations and diversity requires considerable substantial research methodology. The study utilises qualitative methodology with a flexible approach that combines netnography and thematic data analysis techniques. Netnography is an extension of ethnography and it is a "form of ethnographic research, adopting the participant-observational approach and taking online interactions as its fieldwork" (Kozinets 2010, p.1). The online community is advancing as a research stream for qualitative scientist and netnography is one of the recommended approaches to explore diverse cultural disposition of online community and to interpret the result in descriptive or analytical format (Kozinets, Dolbec, \& Earley, 2014; Kozinets, 2015).

In line with the method adopted by Mogaji (2016) and Kozinets (2010)'s recommendations to extract data from the Facebook page of the Big 6 energy providers in UK (British Gas, edf, e.on, npower, ScottishPower, SSE) as a non-bias participantobserver. First, the authors planned the data collection. Second, the data were extracted from the Facebook pages and the data gathered were coded. NCapture, an online capture 
tool was employed for easy transition of the data from the Facebook to the NVivo software.

The collected comments were saved as a PDF and imported into NVivo 10 for analysis using "grounded theory" and following a three-part process. (1) Open coding-breaking down, comparing, conceptualising and categorising data; (2) axial coding-reassembling data into groupings or families; and (3) selective coding-developing core themes brand trust, satisfaction and attachment and relating them to one central concept which is the consumer brand relationship (Strauss \& Corbin, 1990; Mogaji, Farinloye, \& Aririguzoh, 2016).

Esch et al. (2006)'s three constructs of brand relationship were qualitatively operationalised. Brand trust was measured by comments which indicate that the consumers can rely on the energy provider and trust the brand with regards to dealing with their complaints, giving them fair pricing and attending appointments. Brand satisfaction was measured based on either positive or negative comments with regards to their experiences with the brand. This comprises the staff or an engineer on site and how responsive they were with their queries. Brand attachment was operationalised by extracting comments which suggest that consumers are engaging with the brand, either that they feel satisfied and are willing to stay or that they are not satisfied and are considering switching to another energy provider.

\section{Results}

\section{Brand Trust}

From the analysis of comments, trust in the customer-business relationship is breached by three key things: cancelled appointments, complaints not being well handled, and customers feeling unfairly charged. The role of staff in making sure these promises are fulfilled is also highlighted. Customers feel they cannot trust a company that does not return a call as promised or if engineers do not turn up.

[Negative]:Been waiting for my boiler to be fixed. Booked an appointment only to find out it was cancelled, and no one bothered to contact us... Disgusting service... Beyond angry...

[Negative]: Seems to be a custom for this engineer to not ring the bell and just put a card through the post box. So far we had 6 appointments arranged of which 3 they didn't bothered ringing the bell. Please stop advertising this service to other people as the experience it's extremely poor.

Customers want to know there is someone on their side, who takes interest in their complaints and is willing to help them out.

[Negative]: Well I was meant to receive a phone call from the complaints department I believe from 9 a.m. till 2 p.m. today as from now still no phone call do I need to call you to solve this matter or can you give me a call today. 
[Negative]: I've been waiting 3 weeks for your Customer Service Manager to contact me, regarding a complaint. I thought avoiding customer complaints was an Ofgem breach. Can you please confirm what has happened to my complaint and how many other complaints you are hiding?

Aside from broken promises and a poor response to complaints, customers feel that brands lack empathy and often feel that they are being unfairly charged. If these feelings remain the same then they are more likely to move provider.

[Negative]: So I forgot to put gas card in last week. Gas went today, and got charged $28 p$ for debt just because I ran out of gas, I've only been with you for few months and already tempted to switch.

[Negative]: I'm going to need an explanation why living in a single bed flat as a single person for less than a year I've had my direct debit cost risen. I'm leaving EDF ridiculous!! you people are clearly my new year's resolution to be far away from you as possible.

[Negative]: I had to call someone else because BG were going to leave me with 2 young kids with no heating hot water and electric for several days.

\section{Brand Satisfaction}

In understanding the level of satisfaction in the consumer-brand relationship, two key issues emerged as indicators. First, the level of satisfaction with the Boiler Cover provided by the companies. Some have even questioned the worth of this service as they feel it does not offer real value and this is closely followed by the response of their engineers (and the sub-contractors) to emergencies.

[Negative]: Homecare service is terrible. Exhausted going into the detail. Yesterday gas man comes to fix electrical fault and now no show at all. Save your money

[Negative]: Not sure why I pay $£ 21$ a month for a service that is not worth the paper it's written on.

[Negative]: Don't use them! Nearly blew up my parents' house with doggie sub-contractors! Now saying they are not responsible! Avoid at all costs and go with a reputable company!

Second, customers feel dissatisfied with the time it takes them to contact the company by phone. Some even complained about the hold music, which suggests why they see Facebook as a last resort. Some appeared very angry and frustrated, typing in capital letters. Some even decided to take their dissatisfaction to the media and the ombudsman.

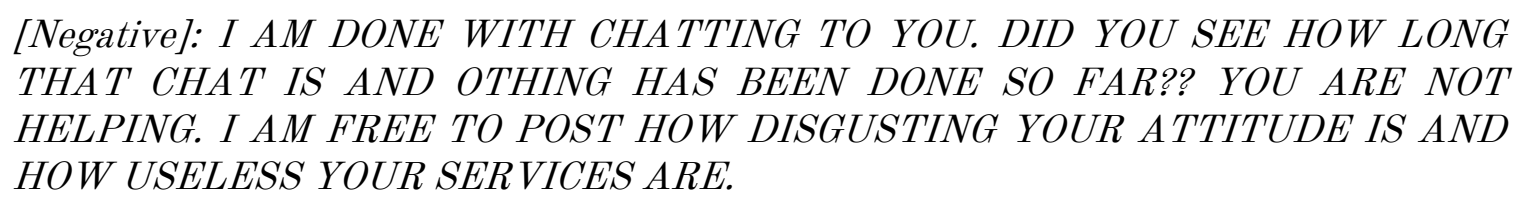

[Negative]: I've logged this thread with BBC Watchdog and Ripoff Britain. This is no longer an "odd case" it's systemic failure! 
[Negative]: Put in a complaint and then if you're not happy push to the ombudsman. They are a joke and breach their own policies, I've now shared this over Facebook.

[Negative]: Ha ha ha ha brilliant-glad it's not just me that finds the hold music irritatingespecially the amount of times you end up listening to it. Never known such bad service from a company (looks consistent unfortunately!)

Evidence shows that overall, UK customers are not satisfied with their relationship with energy companies. However despite this dissatisfaction, Eon stands out as a brand whose customers are at least slightly satisfied with their relationship, as a few customers publicly declared this on their social media.

[Positive]: I have been with Eon for so many years now and have always been good to me. Entered and shared

[Positive]: Best company ever. Been with them 9 years and will carry on

[Positive]: Eon is amazing. Best Energy Company.

\section{Brand Attachment}

Companies were able to engage with their customers and build a sense of attachment. British Gas had 'Wilbur' the penguin as a brand icon and customers felt attached to this. Some wanted a replica of the animal for their family members and the company's social media staff could engage on a closer level with the customers. Eon and npower also engaged their customers by organising competitions, where customers felt attached to the brand as they hoped to win prizes.

[Positive]: Hello British Gas! I was just wondering where I might find the Wilbur the Penguin plushie! My mother-in-law has been always sees the ad on TV, and she absolutely loves him. I'd love to give him to her, it would just brighten up her day!

[Positive]: My daughter Ellie loves penguins, we would love to have a Wilbur come live with us, so she can take good care of him

[Positive]: All done let's hope that long term eon customers win not new ones as they always get best deals y not look after people that gave been loyal to you

However, despite the effort of brands to engage with customers, there are those who questioned this effort and suggested that the brands need to do more than run competitions to build the relationship with their customers.

[Negative]: Is there not a chance that you could just cut our bills instead of giving away "free" stuff!!

[Negative]: Just be honest with your customers and lower your prices instead of giving things away. 
For those who are not attached to the brand through lack of trust or satisfaction, they are more likely to be detached. This closely relates to brand divorce.

[Negative]: Thank you for your provision over the years. With regret I have decided to switch.

\section{Conclusion}

The study sought to extend an understanding of the consumer-brand relationship in the UK energy industry by analysing user-generated content on social media. This study contributes to both theory and practice in several ways. While previous research has typically conceptualised and tested the consumer-brand relationship by using experiments and empirical modelling, the contribution made by this paper is to explore customers' relationship with UK energy brands on social media. To the best of our knowledge it is the only study to have done this.

In addition, the study has qualitatively operationalised and applied the Esch et al. (2006) consumer-brand relationship construct, exploring the interplay between the model and social media data. A limitation of the model was that feedback was not included and this is something we have addressed in our current study, exploring social media content consumers' feedback aids us in understanding brand relationships.

The current study provided insights into social media as a vehicle for customer relationship management. Facebook offers a platform to build and develop a consumerbrand relationship where customers can raise their concerns in a way that they could not do face-to-face or over the phone. This highlights some managerial implications regarding the staff engaging with customers online.

We agree with Sabrina \& Shobeiri (2016) regarding managers' responsibility for creating an appealing brand experience through improving consumer involvement on social media. Often, consumers engage with posts to make complaints and are not necessarily interested in the post's content.

With regards to the 'brand feeling matrix' - one of theoretical frameworks that helps to classify CBR research (Fetscherin \& Heinrich, 2014) - this current study could not place the UK energy consumer-brand relationship into any distinct matrix of brand avoidance and brand divorce. This, perhaps, could be because of the intangible and utilitarian nature of energy services. Even though there is evidence of strong and negative feelings toward brands (shown in consumers indicating their intention to switch providers) it has been found that this negative attitude does not lead to brand divorce, as the rate of switching is still low (Brignall, 2017) and some customers believe the Big Six all offer the same service.

There was little indication of brand alliance or affiliation; energy companies could gain consumers' trust by rewarding loyalty, fair billing, prompt responses to enquiries and differentiating their brands yet making it appealing, as they compete with the Big Six and the numerous smaller providers. 
Energy suppliers are therefore challenged to create values, highlight what is unique about their brand and focus their marketing activities on customer management in order to minimise the defection of those customers willing to switch suppliers to the competition (Walsh, Dinnie, \& Wiedma, 2006).

The study confined itself to the analysis of one post from each of the 6 big energy brands with the analyses of comparatively large sample of comments. Despite that, we urge for cautious generalization of the findings. Sentiment analysis to have a better understanding of consumer sentiment towards a specified subject or brand is considered for future research, Twitter, YouTube and Instagram can also be explored to further understand how the consumer-brand relationship is enhanced. In addition, further research could also evaluate the firms' response mechanisms to these comments. That is, how often do the firms respond to these comments? Do the response assuage the negative feelings of the customers?

The study is based on real marketing communications from the brands and real-life responses from social-media network users and it does not suffer from various issues relating to experimental studies. It is believed that this research technique allows researchers and practitioners to have a greater insight into the brand-customer relationship.

\section{References}

Bengtsson, A. (2003). Towards a Critique of Brand Relationships. In P. A. Keller, \& D. W. Rook (Eds.), Advances in Consumer Research (Vol. 30, pp. 154-158). Valdosta, GA: Association for Consumer Research.

Brignall, M. (2017, December 30). Switching energy supplier: here's what you can save. Retrieved December 31, 2017, from The Guardian: https://www.theguardian.com/money/2017/dec/30/switching-energysupplier-heres-what-you-can-save

Caelli, K., Ray, L., \& Mill, J. (2003). 'Clear as Mud': Toward Greater Clarity in Generic Qualitative Research. International Journal of Qualitative Methods, 2(2), 1 - 13. Retrieved $12 \quad 31, \quad 2017, \quad$ from https://sites.ualberta.ca/ iiqm/backissues/2_2/pdf/caellietal.pdf

Chu, S. (2011). Viral advertising in social media. Journal of Interactive Advertising, $12(1), 30-43$.

Dumbili, E. W., \& Henderson, L. (2017). Mediating alcohol use in Eastern Nigeria: a qualitative study exploring the role of popular media in young people's recreational drinking. Health Education Research, 32(3), 279 - 291.

Energy UK. (2017). Power to everyone: Your guide to energy in the UK. London: Energy UK. Retrieved October 17, 2017, from http://www.energyuk.org.uk/files/docs/Research\%20and\%20reports/Powertoeveryone.pdf

Esch, F.-R., Langner, T., \& Schmit, B. H. (2006). Are brands forever? How brand knowledge and relationships affect current and future purchases. Journal of Product \& Brand Management, 15(2), 98-105.

Fetscherin, M., \& Heinrich, D. (2014). Consumer brand relationships: A research landscape. Journal of Brand Management (2014) 21,, 21(5), 366-371. 
Giovanis, A. (2016). Consumer-brand relationships' development in the mobile internet market: evidence from an extended relationship commitment paradigm. Journal of Product \& Brand Management, 25(6), 568-585.

Izogo, E. E. (2017). Customer loyalty in telecom service sector: the role of service quality and customer commitment. The TQM Journal, 29(1), 19-36.

Kang, J., Tang, L., \& Fiore, A. M. (2014). Enhancing consumer-brand relationships on restaurant Facebook fan pages: Maximizing consumer benefits and increasing active participation. International Journal of Hospitality Management, 36(1), $145-155$.

Karjaluoto, H., Munnukka, J., \& Kiuru, K. (2016). Brand love and positive word of mouth : the moderating effects of experience and price. Journal of Product and Brand Management, 25(6), 527-266.

Kozinets, R. V. (2010). Netnography: Doing ethnographic research online. Sage publications. Thousand Oaks: Sage.

Kozinets, R. V. (2015). Netnography. London: John Wiley.

Kozinets, R. V., Dolbec, P. Y., \& Earley, A. (2014). Netnographic analysis: Understanding culture through social media data. In The SAGE handbook of qualitative data analysis (pp. 262-276).

Mogaji, E. (2016). This advert makes me cry: Disclosure of emotional response to advertisement on Facebook. Cogent Business \& Management, 3(1).

Mogaji, E., \& Danbury, A. (2017). Making the brand appealing: advertising strategies and consumers' attitude towards UK retail bank brands. Journal of Product \& Brand Management, 26(6), 531-544.

Mogaji, E., Farinloye, T., \& Aririguzoh, S. (2016). Factors shaping attitudes towards UK bank brands: An exploratory analysis of social media data. Cogent Business \& Management, 3(1). doi:https://doi.org/10.1080/23311975.2016.1223389

Mogaji, E., Farinloye, T., \& Aririguzoh, S. A. (2016). Factors shaping attitudes towards UK bank brands: An exploratory analysis of social media data. Cogent Business \& Management, 3(1), 1223389. Retrieved 12 31, 2017, from http://tandfonline.com/doi/abs/10.1080/23311975.2016.1223389

Pawle, J., \& Cooper, P. (2006). Measuring emotion - lovemarks, the future beyond brands. Journal of Advertising Research, 46(1), 38-48.

Rogers, J. F. (2014, April 11). Public attitudes to the household energy market. Retrieved October 11, 2017, from YouGov: https://yougov.co.uk/news/2014/04/11/british-attitudes-household-energymarket/

Sabrina, T. H., \& Shobeiri, S. (2016). The relative impacts of experiential and transformational benefits on consumer-brand relationship. Journal of Product \& Brand Management, 25(6), 586-599.

Strauss, A., \& Corbin, J. (1990). Basics of qualitative research: Grounded theory procedures and techniques. London: Sage.

Tsai, W. H., \& Men, L. R. (2013). Motivations and antecedents of consumer engagement with brand pages on social networking sites. , 13(2), pp. Journal of Interactive Advertising, 13(2), 76-87.

Tuškej, U., Golob, U., \& Podnar, K. (2013). 2013. The role of consumer-brand identification in building brand relationships. Journal of Business Research, $66(1), 53-59$. 
Vaughan, A. (2017, December 21). Shell to supply energy to UK households after takeover of First Utility. Retrieved from The Guardian: https://www.theguardian.com/business/2017/dec/21/shell-to-supply-energyto-uk-households-after-takeover-of-first-utility

Veloutsou, C. (2015). Brand evaluation, satisfaction and trust as predictors of brand loyalty: the mediator-moderator effect of brand relationships. Journal of Consumer Marketing, 32(6), 405-421.

Walsh, G., Dinnie, K., \& Wiedma, K.-P. (2006). How do corporate reputation and customer satisfaction impact customer defection? A study of private energy customers in Germany. Journal of Services Marketing, 20(6), 412-420. 